Brit. J. industr. Med., 1956, 13, 187.

\title{
A STUDY OF DUST TOXICITY USING A QUANTITATIVE TISSUE CULTURE TECHNIQUE
}

\author{
BY \\ J. MARKS, M. ANN MASON, and G. NAGELSCHMIDT \\ From the Central Tuberculosis Laboratory, Cardiff, the Pneumoconiosis Research Unit, Cardiff, and the Safety in Mines \\ Research Establishment, Sheffield
}

(RECEIVED FOR PUBLICATION JANUARY 20, 1956)

A number of workers have employed tissue culture techniques in pneumoconiosis research since Fenn (1921) examined the phagocytosis of quartz and coal by rat exudate leucocytes. However, most attention has been directed to the degree of phagocytosis achieved rather than to evaluating accurately the toxicity of dust to the phagocytic cell. Moreover, the techniques used did not provide concordant results in the hands of different workers. For example, Policard, Doubrow, and Boucharlat (1929) found that chick embryo macrophages were damaged by ingested quartz whereas Lauche (1931) observed no effect. Kasten (1939) and Belt, Friedmann, and King (1947) found coal was phagocytosed more readily than quartz whereas Buckup (1950) did not detect any difference. A quantitative study of the phagocytosis of quartz was undertaken by Marwyck and Fischer (1951).

Policard and Collet (1953) have injected dusts intraperitoneally into rats and examined the exudate phagocytes after five to 20 hours in an attempt to estimate dust toxicity. However, the phagocytes were not maintained in tissue culture and their observations were qualitative only.

A technique has been recently described (Marks and Mason, 1956) which permits a quantitative assessment of dust toxicity in tissue culture in three days. It has now been used to compare the toxicity of a number of dusts of interests in the field of pneumoconiosis and to examine the effect of protective agents. The chief purpose of the investigation was to determine whether the short-term toxicity of dusts as seen in tissue culture is related to their reported effect in vivo in animal experiments. In these, the amount and maturity of silicotic type lesions have usually been taken as an index of pathogenicity in experiments lasting several months or sometimes one or more years.

\section{Methods and Materials}

The technique employed in the present investigation was the same as that previously recorded using guinea-pig exudate cells but the explanation of the symbols used to record dust toxicity will be repeated for convenience:-

+ Considerably fewer cells adhere to the glass than in the controls. They are optically denser and less active than normal cells, a large proportion being partially or completely rounded off.

++ Less than $10 \%$ of the cells remain on the glass. Most of the survivors are optically dense whether rounded off or not.

+++ Fewer than 50 cells remain (inoculum $=2 \times 10^{6}$ cells).

Intermediate degrees of damage designated trace, + \pm , and ++ \pm , were also recognized.

Experience showed that determinations of dust toxicity were most reproducible when a moderate degree of damage was taken as the end-point of titrations. The end-point, which can conveniently be used to express the degree of toxicity, was therefore defined as the smallest concentration of dust (in $\mu \mathrm{g}$. per $10^{6}$ cells) required to produce in three days cell damage of the degree + \pm or ++ (standard damage). A reference dust (tridymite 2612) was normally titrated in each experiment as a check on the experimental conditions.

With the exception of four dusts presented by Dr. B. M. Wright, the materials used in the present work were prepared at the Safety in Mines Research Establishment, Sheffield. Information available about their size is summarized in Table 1.

Most of the dusts were fractions graded by size primarily prepared for the animal experiments of Professor E. J. King and his colleagues. The particle size distribution was determined by counting and sizing with the optical or electron microscope. The specific surface was calculated from the size distribution and for several of the dusts checked by air permeability determinations. These gave good agreement for specific surfaces between 0.5 and $3 \mathrm{~m}^{2} / \mathrm{g}$. for isometric materials such as felspar, silica modifications, and coal. The plate-shaped minerals kaolin and mica were used in 
TABLE 1

SPECIFIC SURFACE AND SIZE DISTRIBUTION OF DUST SAMPLES EMPLOYED IN THE PRESENT WORK

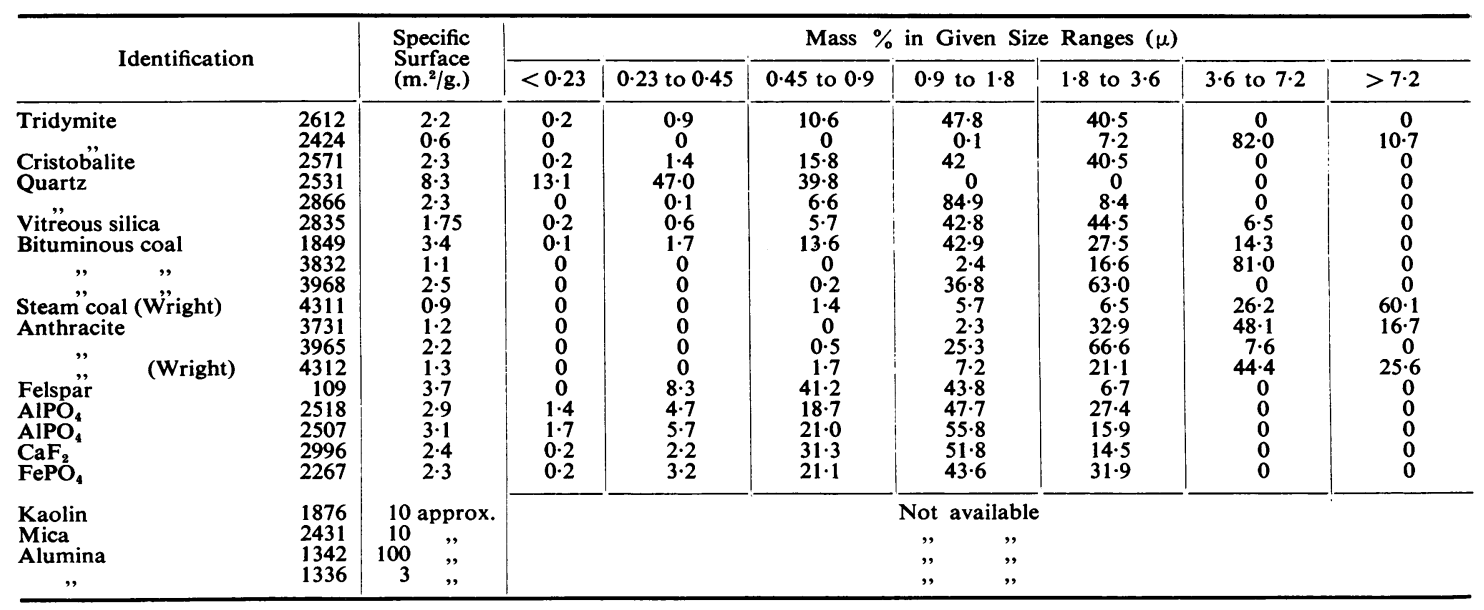

fractions below $4 \mu$ Stokes diameter, and the projected diameters of the particles did not exceed $10 \mu$. However, as the ratio of diameter to thickness was unknown and variable, the specific surface could not be determined accurately and the value of $10 \mathrm{~m} .{ }^{2} / \mathrm{g}$. cited is only a rough estimate.

\section{Results}

Different Forms of Silica.-The effect on replicate leucocyte cultures of vitreous silica and the three crystalline forms, tridymite, cristobalite, and quartz, was examined. The samples chosen were fairly similar in particle size, their specific surfaces approximating to $2 \mathrm{~m} .{ }^{2} / \mathrm{g}$. The toxicity titrations obtained in a representative experiment are shown in Table 2. Tridymite and cristobalite behaved similarly, producing the standard degree of cell damage in a concentration of $7 \cdot 5 \mu \mathrm{g}$. per $10^{6}$ cells. Quartz and vitreous silica were eight times less toxic, the standard toxic dose being $60 \mu \mathrm{g}$. per $10^{6}$ cells in both cases.

Particle Size.-The effect of dust samples with different ranges of particle size was studied using tridymite and quartz. The results of typical titrations presented in Table 3 show that toxicity increased with the specific surface' of the dust sample. King, Mohanty, Harrison, and Nagelschmidt (1953a) observed a similar relation in vivo between the fibrogenic activity and specific surfaces of flint dust samples administered in equal weights.

Silicates.-One sample each of felspar, mica, and kaolin dusts was examined. The specific surfaces of

TABLE 2

EFFECT OF DIFFERENT FORMS OF SILICA ON EXUDATE CELL CULTURES

\begin{tabular}{|c|c|c|c|c|c|c|c|c|c|c|}
\hline \multirow{2}{*}{\multicolumn{2}{|c|}{ Dust Sample }} & \multirow{2}{*}{$\begin{array}{l}\text { Specific } \\
\text { Surface } \\
\left(\mathrm{m} .^{2} / \mathrm{g} .\right)\end{array}$} & \multicolumn{8}{|c|}{ Toxicity of Given Dust Concentrations ( $\mu \mathrm{g} . / 10^{6}$ cells) } \\
\hline & & & 120 & 60 & 30 & 15 & $7 \cdot 5$ & $3 \cdot 7$ & 1.8 & 0.9 \\
\hline $\begin{array}{l}\text { Tridymite } \\
\text { Cristobalite } \\
\text { Quartz } \\
\text { Vitreous silica }\end{array}$ & $\begin{array}{l}2612 \\
2571 \\
2866 \\
2835\end{array}$ & $\begin{array}{l}2 \cdot 2 \\
2 \cdot 3 \\
2 \cdot 3 \\
1 \cdot 65\end{array}$ & $\begin{array}{l}+++ \\
+++ \\
++t \\
++t\end{array}$ & $\begin{array}{l}++t \\
++t \\
+ \pm \\
+t\end{array}$ & $\begin{array}{c}+++ \\
+++ \\
\text { Trace } \\
+\end{array}$ & $\begin{array}{c}++ \\
++ \\
\text { Trace } \\
\text { Trace }\end{array}$ & $\begin{array}{c}+ \pm^{*} \\
+ \pm \\
0 \\
0\end{array}$ & $\begin{array}{l}+ \\
+ \\
0 \\
0\end{array}$ & $\begin{array}{c}\text { Trace } \\
\text { Trace } \\
0 \\
0\end{array}$ & $\begin{array}{l}0 \\
0 \\
0 \\
0\end{array}$ \\
\hline
\end{tabular}

*Figures in bold type are the titration end-points.

TABLE 3

EFFECT OF SPECIFIC SURFACE ON TOXICITY IN EXUDATE CELL CULTURES

\begin{tabular}{|c|c|c|c|c|c|c|c|c|c|}
\hline \multirow{2}{*}{\multicolumn{2}{|c|}{ Dust Sample }} & \multirow{2}{*}{$\begin{array}{l}\text { Specific } \\
\text { Surface } \\
\left(\mathrm{m} .^{2} / \mathrm{g} .\right)\end{array}$} & \multicolumn{7}{|c|}{ Toxicity of Given Dust Concentrations ( $\mu \mathrm{g} . / 10^{\circ}$ cells) } \\
\hline & & & 120 & 60 & 30 & 15 & $7 \cdot 5$ & $3 \cdot 7$ & $1 \cdot 8$ \\
\hline $\begin{array}{l}\text { Tridymite } \\
\text { Tridymite } \\
\text { Quartz } \\
\text { Quartz }\end{array}$ & $\begin{array}{l}2612 \\
2424 \\
2531 \\
2866\end{array}$ & $\begin{array}{l}2 \cdot 2 \\
0 \cdot 6 \\
8 \cdot 3 \\
2 \cdot 3\end{array}$ & $\begin{array}{c}+++ \\
+++ \\
+++ \\
++\end{array}$ & $\begin{array}{c}+++ \\
++ \\
++ \pm \\
+ \pm\end{array}$ & $\begin{array}{c}+++ \\
+ \pm \\
+ \pm \\
\text { Trace }\end{array}$ & $\begin{array}{c}++ \\
\text { Trace } \\
\text { Trace } \\
0\end{array}$ & $\begin{array}{c} + \pm * \\
0 \\
\vdots\end{array}$ & $\begin{array}{c}+ \\
0 \\
.\end{array}$ & $\begin{array}{c}\text { Trace } \\
0 \\
\cdot \\
\cdot\end{array}$ \\
\hline
\end{tabular}

*Figures in bold type are the titration end-points. 
TABLE 4 COMPARISON OF EFFECTS OF SILICATES AND QUARTZ AND TRIDYMITE ON EXUDATE CELL CULTURES

\begin{tabular}{|c|c|c|c|c|c|c|c|c|}
\hline \multirow{2}{*}{\multicolumn{2}{|c|}{ Dust Sample }} & \multirow{2}{*}{$\begin{array}{l}\text { Specific } \\
\text { Surface } \\
\left(\mathrm{m} .^{2} / \mathrm{g} .\right)\end{array}$} & \multicolumn{6}{|c|}{ Toxicity of Given Dust Concentrations ( $\mu \mathrm{g} . / 10^{6}$ cells) } \\
\hline & & & 120 & 60 & 30 & 15 & $7 \cdot 5$ & $3 \cdot 7$ \\
\hline $\begin{array}{l}\text { Kaolin } \\
\text { Felspar } \\
\text { Mica } \\
\text { Quartz } \\
\text { Tridymite }\end{array}$ & $\begin{array}{r}1876 \\
109 \\
2431 \\
2531 \\
2612\end{array}$ & $\begin{array}{c}10 \\
3 \cdot 7 \\
10 \\
8 \cdot 3 \\
2 \cdot 2\end{array}$ & $\begin{array}{c}+++ \\
+++ \\
++ \\
+++ \\
+++\end{array}$ & $\begin{array}{c}+++ \\
++ \\
+ \\
++ \\
++\end{array}$ & $\begin{array}{c}\mathbf{T}^{+*} \\
0 \\
+ \pm \\
+++\end{array}$ & $\begin{array}{c}\text { Trace } \\
0 \\
0 \\
\text { Trace } \\
+++\end{array}$ & $\begin{array}{r}\dot{ } \\
+\dot{+}\end{array}$ & $\dot{\dot{ }} \dot{ }$ \\
\hline
\end{tabular}

the latter two samples at an estimated $10 \mathrm{~m} .{ }^{2} / \mathrm{g}$. were probably considerably greater than those of the other dusts investigated. The silicates proved unexpectedly toxic, the effect of kaolin and felspar being as great as that of quartz although much less than that of tridymite. Mica was less toxic than the other two silicates. Details of an experiment in which silicates, quartz, and tridymite were compared are given in Table 4.

Coal.-Phagocytes appeared to suffer no harm from coal unless burdened with very large amounts. With such dosages it was uncertain whether the rounding off of the cells and their detachment from the glass should be considered as evidence of toxicity or merely of overloading. Many cells retained their activity despite the ingestion of very large amounts of coal but it should be noted that except in sample 1849 there were no very small particles. When coal was administered as a suspension in Ringer's solution the standard degree of cell damage was produced by all three samples of anthracite in a dosage of $240 \mu \mathrm{g}$. per $10^{6}$ cells but not by bituminous or steam coal. It was noted that the latter varieties, especially sample 3968 , suspended poorly and appeared to be taken up by the phagocytes less well than anthracite. An attempt was made to improve the dispersion of coal particles by first suspending them in concentrations of $6 \mathrm{mg}$. per $\mathrm{ml}$. in $66 \%$ serum or in a preparation of $1 \%$ (approximately) lecithin in Ringer's solution. Better coal suspensions were obtained in both cases and the phagocytosis of the bituminous varieties greatly increased. With these modifications the effects of the bituminous and steam coal samples approached those of the anthracite without quite equalling them. It appears likely, therefore, that differences observed between the effects of bituminous orsteam coal and anthracite on leucocyte cultures were due only to the difficulty in dispersing the former in suspensions.

The toxicity of combinations of kaolin or felspar with different coals appeared to be additive.

Other Types of Dust.-The following dusts were examined which had previously been studied in animal experiments (Professor E. J. King, personal communication): ferric phosphate, calcium fluoride, and two types each of aluminium phosphate and alumina. They are described in Tables 1 and 5 .

The highest concentration of these dusts tested was $120 \mu \mathrm{g}$. per $10^{6}$ cells which was normally in excess of what could be phagocytosed. Ferric phosphate and $\alpha$-alumina had a negligible effect on leucocyte cultures. The toxicity of aluminium phosphate was definite but not sufficient to produce standard cell damage and was unrelated to the crystalline form. Alumina which had been heated to $820^{\circ} \mathrm{C}$. produced standard cell damage in a concentration of $120 \mu \mathrm{g}$. per $10^{6}$ cells. Calcium fluoride produced the degree of damage designated ++ in a concentration of $60 \mu \mathrm{g}$. per $10^{6}$ cells, being the only dust of the group to approach quartz in its toxicity. The results obtained in a typical experiment are shown in Table 5. They demonstrate a correlation between toxicity for leucocytes in vitro and the

TABLE 5

EFFECT ON EXUDATE CELL CULTURES OF DUSTS WITH DIFFERENT FIBROGENIC ACTIVITIES

\begin{tabular}{|c|c|c|c|c|c|c|c|}
\hline \multirow{2}{*}{\multicolumn{2}{|c|}{ Dust Sample }} & \multirow[t]{2}{*}{ Mineral Type } & \multirow{2}{*}{$\begin{array}{l}\text { Fibrogenic } \\
\text { Activity } \\
\text { in vivo }\end{array}$} & \multicolumn{4}{|c|}{$\begin{array}{c}\text { Toxicity of Given Dust Concentrations } \\
\qquad\left(\mu \mathrm{g} . / 10^{6} \text { cells }\right)\end{array}$} \\
\hline & & & & 120 & 60 & 30 & 15 \\
\hline $\begin{array}{l}\text { AlPO, } \\
\text { AlPO, } \\
\text { FePO, } \\
\text { Alumina } \\
\quad\left(H X 1010 \text { heated to } 820^{\circ} \mathrm{C} \text {. for } 1 \mathrm{hr} \text {.) }\right.\end{array}$ & $\begin{array}{l}2518 \\
2507 \\
2267 \\
1342\end{array}$ & $\begin{array}{l}\text { Crystal structure like quartz } \\
\text { Crystal structure like tridymite } \\
\text { Crystal structure like quartz } \\
\gamma \text {-alumina }\end{array}$ & $\begin{array}{l}\text { Strong } \\
\text { Strong } \\
\text { None } \\
\text { Strong }\end{array}$ & $\begin{array}{c}+ \\
+ \\
\text { Trace } \\
+ \pm\end{array}$ & $\begin{array}{c}\text { Trace } \\
\text { Trace } \\
\quad 0 \\
+\end{array}$ & $\begin{array}{c}0 \\
0 \\
0 \\
\text { Trace }\end{array}$ & $\begin{array}{l}0 \\
0 \\
0 \\
0\end{array}$ \\
\hline (HX1010 heated to $1220^{\circ} \mathrm{C}$. for $5 \mathrm{hr}$.) & 1336 & $\alpha$-alumina & & Trace & 0 & 0 & 0 \\
\hline $\mathrm{CaF}_{2}$ & 2996 & Fluorspar & Weak $†$ & +++ & ++ & Trace & $\mathbf{0}$ \\
\hline
\end{tabular}

* Figures in bold type are the titration end-points.

†Policard and Collet (1952) found considerable activity in vivo. 
TABLE 6

PROTECTION OF EXUDATE CELL CULTURES BY POTASSIUM ALUM AGAINST TOXIC EFFECT OF SILICA AS TRIDYMITE

\begin{tabular}{|c|c|c|c|c|c|}
\hline \multirow{2}{*}{$\begin{array}{l}\text { Final Concentration of } \\
\mathrm{KAl}\left(\mathrm{SO}_{4}\right)_{2} \times 10^{-5} \mathrm{M}\end{array}$} & \multirow{2}{*}{$\begin{array}{l}\text { Equivalent } \mathrm{Al} \text { Concentration } \\
\left(\mu \mathrm{g} . / 10^{6} \text { cells }\right)\end{array}$} & \multicolumn{4}{|c|}{$\begin{array}{l}\text { Toxic Effect with Given Tridymite Concentrations } \\
\left(\mu \mathrm{g} . / 10^{6} \text { cells }\right)\end{array}$} \\
\hline & & 30 & 15 & $7 \cdot 5$ & Nil. \\
\hline
\end{tabular}

fibrogenic activity reported for the same dusts in vivo.

Inhibition of Silica Toxicity.-Experiments of the type shown in Table 6 were set up in which different concentrations of silica (tridymite 2612) were added to leucocyte cultures along with varying amounts of a potential antagonist. Antagonists were used in concentrations found by preliminary experiment to have little or no effect themselves on the cells. The most potent of those examined was potassium aluminium sulphate which protected cells very considerably against the effect of silica, presumably by virtue of aluminium hydroxide formed at the $p \mathrm{H}$ of the culture medium $(7 \cdot 2-7 \cdot 4)$. Alumina HX 1010 (unheated), the preparation used by Gardner, Dworski, and Delahant (1944) to depress silica activity in vivo, provided only a slight degree of protection in tissue culture. A mixture of aluminium metal dust and alumina was very slightly more protective than alumina alone. Iron in the form of ferric chloride had a weak protective effect against silica, not greater than that of alumina. Mica and felspar dusts were also slightly protective but kaolin was not. The concentrations used of these three dusts were 30,15 , and $7 \cdot 5 \mu \mathrm{g}$. per $10^{6}$ cells respectively, the highest possible concentrations without causing confusion by their own toxicity.

\section{Discussion}

The relative toxicity of different forms of silica to leucocytes in tissue culture found in the present work agreed well with their pathogenicity and fibrogenic qualities in vivo as described by Gardner (1938) and by King and others (1953b). The high toxicity of cristobalite found in vitro is of interest since this type of silica has been reported to be responsible for a particularly severe form of silicosis in man (Vigliani and Mottura, 1948). Fairly close agreement was also found between the toxicity in tissue culture and the effects in vivo of aluminium and ferric phosphate and alumina heated to different degrees reported by King. King has found calcium fluoride weakly fibrogenic but the tissue culture results accord better with those of Policard and
Collet (1953) who found calcium fluoride as pathogenic as quartz when injected intraperitoneally into rats. Coal dust which is relatively harmless in vivo had little effect on leucocyte cultures unless the cells were grossly overloaded with it. No clear difference related to type of coal could be demonstrated.

It appears probable from the correlation now demonstrated between fibrogenic activity and toxicity to leucocytes that injury to the phagocytic cell by dust is the stimulus for fibrous tissue formation in pneumoconiosis. In the intact animal this stimulus is presumably maintained for long periods by the continuous recruitment of fresh macrophages replacing those that die. In addition, no doubt, many of the cells containing low concentrations of dust survive for considerable periods during which time they might suffer damage and promote fibrosis.

The inhibition of silica toxicity by alumina in animals reported by Gardner and others (1944) and that by iron reported by Kettle (1932) have been reproduced in tissue culture although in neither case was the protection in vitro striking. However, the concentrations of iron used in the present work $\left(10^{-3}\right.$ to $\left.10^{-4} \mathrm{M}\right)$ are difficult to compare with those used by Kettle who coated silica particles with two-thirds of their weight of iron oxide. Gardner found great differences between the protective powers of different batches of alumina and it is possible that his most potent sample, HX 1010, which was used in the present work, has deteriorated. In contrast to the relatively weak actions of alumina and iron, considerable protection against silica toxicity was afforded to leucocytes by potassium alum, no doubt by means of aluminium hydroxide formed in the culture medium. The toxicity of silica was also found to be reduced in tissue culture by felspar and mica dusts, recalling the unexpectedly slight effect in vivo of quartz accompanied by these minerals in the form of granite as reported by Gardner (1938) and King, Ray, Harrison, and Nagelschmidt (1950).

The silicates, particularly kaolin and felspar, produced effects in vitro for which there have been no clear-cut equivalents in vivo. In experimental 
animals the silicates produce far less fibrosis than does quartz (Cummins, 1937; King, Harrison, and Nagelschmidt, 1948; Mohanty, Roberts, King, Harrison, and Nagelschmidt, 1953). However, the published experimental work is not altogether consistent. . For example, Kettle (1932) produced necrotic lesions in mice by the subcutaneous injection of kaolin, and Rüttner, Bovet, Weber, and Willy (1952) fibrous nodules by intraperitoneal injection. Mica was found lethal to phagocytes by Lemon and Higgins (1935) and by Policard (1934). A complicating factor has been introduced by the observation of Belt and King (1945) and King, Gilchrist, and Rae (1947) that the fibrogenic activity of mica was greatly increased if the dust had been treated with acid. This finding suggests that the effect of silicates in tissue culture may have depended to some extent on the experimental conditions and that investigation into the influence of these would be desirable.

It is not intended to suggest on the basis of the present work that tissue culture could be used to estimate the fibrogenic activity of different dusts. A much more comprehensive investigation than the present one would be necessary to define the utility of the technique in this respect. It does appear, however, that the rapidity and sensitivity of the quantitative tissue culture technique described above should make it useful for screening substances for protective action against dust toxicity and for investigating the mechanism of such toxicity. In the latter case a useful line of approach would appear to be the physical and chemical modification of the surface of dust particles, and a biochemical study of the mechanism of cell damage. The difference between the biological effects of tridymite and cristobalite on one hand and quartz and vitreous silica on the other requires investigation in this manner, as does the augmenting action of fluorine etching on the pathogenicity of quartz (King and others, 1953c).

\section{Summary}

A fairly close agreement was found between the toxicity to leucocytes in vitro of a number of dusts of interest in the field of pneumoconiosis and their fibrogenic activity as reported by other workers. Silicates proved more toxic in tissue culture, however, than experiments on animals would have suggested. Silica toxicity to leucocytes in vitro is antagonized by certain aluminium compounds.

We are indebted to Professor J. Gough for helpful comments on the paper.

\section{REFERENCES}

Belt, T. H., and King, E. J. (1945). Spec. Rep. Ser. med. Res. Coun. Lond.), No. 250, p. 29.

Friedmann, I., and King, E. J. (1947). J. Path. Bact., 59, 159.

Buckup, H. (1950). Arch. Hyg. (Berl.), 132, 273.

Bummins, $\mathrm{s}$.

Cummins, S. L. (1937). Brit. J. exp. Path.,

Fenn, W. O. (1921). J. gen. Physiol., 3, 439. p. 257. Oxford Univ. Press, London.

Dworski, M., and Delahant, A. B. (1944). J. industr. Hyg., 26, 211 .

Kasten, W. (1939). Arch. Gewerbepath. Gewerbehyg., 9, 337.

Kettle, E. H. (1932). J. Path. Bact., 35, 395.

King, E. J., Gilchrist, M., and Rae, M. V. (1947). Ibid., 59, 324.

-, Harrison, C. V., and Nagelschmidt, G. (1948). Ibid., 60, 435. Mohanty, G. P., Harrison, C. V., and Nagelschmidt, G. (1953a). British Journal of Industrial Medicine, 10, 76.

_-, , - _ , (1953b). Ibid., 10, 9.

二, 二,, (1953c). Arch. industr. Hyg., 7, 455.

Ray, S. C., Harrison, C. V., and Nagelschmidt, G. (1950).

British Journal of Industrial Medicine, $7,37$.
Lauche, A. (1931). Verh. dtsch. path. Ges., 26, 107.

Lauche, A. (1931). Verh. dtsch. path. Ges., 26, 107. 32, 243 .

Marks, J., and Mason, M. A. (1956). British Journal of Industrial Medicine, 13, 38 .

Marwyck, C. van, and Fischer, E. (1951). Arch. Hyg. (Berl.), 135, 161

Mohanty, G. P., Roberts, D. C., King, E. J., Harrison, C. V., and Nagelschmidt, G. (1953)., J. Path. Bact., 65, 501.

Policard, A. (1934). J. industr. Hyg., 16, 160.

.

Doubrow, S., and Boucharlat, M. (1929). C.R. Acad. Sci. (Paris), 189, 593 .

Rüttner, J. R., Bovet, P., Weber, R., and Willy, W. (1952). Naturwissenschaften, 39, 332.

Vigliani, E. C., and Mottura, G. (1948). British Journal of Industrial Medicine, 5, 148. 